\title{
Angiotensin II Blocks Nicotine-Mediated Neuroprotection against $\beta$-Amyloid (1-42) via Activation of the Tyrosine Phosphatase SHP-1
}

\author{
Seán Shaw, ${ }^{1}$ Merouane Bencherif, ${ }^{3}$ and Mario B. Marrero ${ }^{1,2}$ \\ ${ }^{1}$ Vascular Biology Center and ${ }^{2}$ Department of Pharmacology and Toxicology, Medical College of Georgia, Augusta, Georgia 30912, and ${ }^{3}$ Targacept Inc., \\ Winston-Salem, North Carolina 27101-4165
}

We showed recently that nicotine activates the growth-promoting enzyme Janus kinase 2 (JAK2) in PC12 cells and that preincubation of these cells with the JAK2-specific inhibitor AG-490 blocked the nicotine-induced neuroprotection against $\beta$-amyloid (1-42) [A $\beta$ (1-42)]. These results provided direct evidence for linkage between JAK2 and the $\alpha 7$ nicotinic acetylcholine receptor-induced neuroprotection in PC12 cells. We also showed that preincubation with angiotensin II (Ang II), functioning via the angiotensin II type 2 (AT 2 ) receptor, blocked both the nicotine-induced activation of JAK2 and its neuroprotection against A $\beta(1-42)$. Recently growth-inhibitory effects of the $\mathrm{AT}_{2}$ receptor have been reported to be mediated by the activation of protein tyrosine phosphatases (PTPases) and that $\mathrm{AT}_{2}$ receptor stimulation is associated with a rapid activation of the PTPase SHP-1 (the cytoplasmic tyrosine phosphatase that contains Src homology 2 domains), a negative regulator of JAK2 signaling. Therefore, the potential biological significance of $\mathrm{AT}_{2}$ receptor-induced effects on both the nicotine-induced activation of JAK2 and its neuroprotection against A $\beta$ (1-42) led us to investigate whether SHP-1 activation could be involved in this process. We found that Ang II induced the activation of SHP-1 and that an antisense against SHP-1 not only augmented the nicotine-induced tyrosine phosphorylation of JAK2 but also blocked the Ang II neutralization of the nicotine-induced neuroprotection. These results demonstrate that nicotine-induced tyrosine phosphorylation of JAK2 and neuroprotection against A $\beta$ (1-42) in PC12 cells are blocked by Ang II via $\mathrm{AT}_{2}$ receptor-induced activation of SHP-1.

Key words: nicotine; neuroprotection; JAK2; phosphatydylinositol-3-kinase; SHP-1; PC12 cells; Alzheimer's disease; Ang II

\section{Introduction}

The cholinergic deficit in Alzheimer's disease (AD) has been clearly established and is the basis for the current symptomatic strategy. There is an early and significant depletion of highaffinity nicotinic receptors in Alzheimer's patient's brains (Court et al., 2001), and a number of studies have shown cognitive improvement in rodent, primates, and humans after administration of ligands targeting nicotinic acetylcholine receptor (nAChR) (Newhouse et al., 2001). In addition to their known symptomatic effects, neuronal nicotinic ligands have shown neuroprotective activity in vitro (Donnelly-Roberts et al., 1996) and in vivo (Ryan et al., 2001), suggesting an additional potential for disease modification.

The $\alpha 7 \mathrm{nAChR}$ forms functional homomeric ligand-gated ion channels that promote rapidly desensitizing $\mathrm{Ca}^{2+}$ influx, is widely expressed throughout the mammalian brain, and has been implicated in sensory gating, cognition, and neuroprotection (Seo et al., 2001). In addition, nicotine-induced neuroprotection against $\beta$-amyloid [A $\beta(1-42)]$-induced toxicity is suppressed by $\alpha$-bungarotoxin, and the selective $\alpha 7 \mathrm{nAChR}$ agonist anabaseine-

Received April 16, 2003; revised 0ct. 7, 2003; accepted 0ct. 10, 2003.

This study was supported by National Institutes of Health Grant HL58139 and Targacept Inc.

Correspondence should be addressed to Dr. Mario B. Marrero, Vascular Biology Center, Medical College of Georgia, Augusta, GA 30912-2500.E-mail: mmarrero@mail.mcg.edu.

Copyright $\odot 2003$ Society for Neuroscience $\quad$ 0270-6474/03/2311224-05\$15.00/0 derived 3-(4)-dimethylaminocinamylidine exerts cytoprotective effects (de Fiebre et al., 1995; Kem, 2000). Furthermore, a recent study has reported that the levels of phosphorylated Akt, an effector of phosphatidylinositol 3-kinase (PI-3-K), are increased by nicotine, and the nicotine-induced cytoprotective effects are suppressed by the PI-3-K inhibitors (LY294002 and wortmannin) (Kihara et al., 2001). These findings suggest that the $\alpha 7 \mathrm{nAChR}$ transduces signals to PI-3-K in a cascade, which ultimately contributes to a neuroprotective effect against $\mathrm{A} \beta$ (1-42).

We recently provided evidence for the nicotine-induced complex formation between the $\alpha 7 \mathrm{nAChR}$ and the tyrosine kinase enzyme Janus kinase 2 (JAK2), which results in subsequent activation of PI-3-K and Akt (Shaw et al., 2002). We also provided evidence that nicotine interaction with the $\alpha 7 \mathrm{nAChR}$ is "dominant" over $\mathrm{A} \beta$ (1-42) interaction with the receptor and that the $\mathrm{A} \beta$ (1-42)-induced apoptosis is prevented through the nicotineinduced activation of JAK2. Nicotine neuroprotective effects can be neutralized through activation of the angiotensin II (Ang II) type $2\left(\mathrm{AT}_{2}\right)$ receptor as evidenced by the reversal of JAK2 phosphorylation and inhibition of nicotine-induced neuroprotection (Shaw et al., 2002).

The $\mathrm{AT}_{2}$ receptor exerts growth-inhibitory effects in cultured cells and in vivo, one of which has been proposed to be programmed cell death (Horiuchi et al., 1998; Lehtonen et al., 1999). Despite growing interest in $\mathrm{AT}_{2}$ receptor-mediated apoptosis, 
relatively little is known about the molecular basis of this process. Recently, growth-inhibitory effects of the $\mathrm{AT}_{2}$ receptor have been reported to be mediated by the activation of protein tyrosine phosphatases (PTPases) (Horiuchi et al., 1998), and, in rat pheochromocytoma PC12 cells, $\mathrm{AT}_{2}$ receptor stimulation is associated with a rapid activation of SHP-1 ((the cytoplasmic tyrosine phosphatase that contains Src homology 2 domains) (Horiuchi et al., 1998). However, at present, no functional role has been demonstrated for SHP-1 activation by the $\mathrm{AT}_{2}$ receptor, and it is interesting to note that SHP-1 has been shown to function as a negative regulator of JAK2 signaling (Marrero et al., 1998). Therefore, the potential biological significance of $\mathrm{AT}_{2}$ receptor-induced effects on both the nicotine-induced activation of JAK2 and its neuroprotection against $\mathrm{A} \beta$ (1-42) led us to investigate whether SHP-1 activation could be involved in this process.

\section{Materials and Methods}

Materials. Molecular weight standards, acrylamide, SDS, N-N'methylene-bisacrylamide, $N, N, N^{\prime}, N^{\prime}$-tetramethylenediamine, protein assay reagents, and nitrocellulose membranes were purchased from BioRad (Hercules, CA). Protein A/G-agarose was obtained from Santa Cruz Biotechnology (Santa Cruz, CA), and DMEM, fetal bovine serum, trypsin, and all medium additives were obtained from Mediatech (Herndon, VA). Monoclonal antibody to phosphotyrosine (PY20) and SHP-2 were procured from Transduction Laboratories (Lexington, KY). Poly-(ADPribose) polymerase (PARP) antibodies were purchased from New England Biolabs (Beverly, MA). Anti-phosphotyrosine JAK2 and JAK2 antibodies were obtained from Biosource (Camarillo, CA). The Pierce Supersignal substrate chemiluminescence detection kit was obtained from Pierce (Rockford, IL). Goat anti-mouse IgG and anti-rabbit IgG were acquired from Amersham Biosciences (Princeton, NJ), and Tween 20 , nicotine, $\mathrm{A} \beta$ (1-42) peptide, anti-A $\beta$ (1-42), anti- $\alpha 7 \mathrm{nAChR}$, and all other chemicals were purchased from Sigma (St. Louis, MO).

Isolation and culture of PC12 cells. PC12 rat pheochromocytoma cells were maintained in proliferative growth phase in DMEM (Invitrogen, Gaithersburg, MD) supplemented with 10\% horse serum, 5\% fetal calf serum (Atlanta Biologicals, Norcross, GA), and antibiotics (penicillinstreptomycin) according to routine protocols (Bencherif et al., 1996).

Western blotting studies of JAK2. The phosphorylation of JAK2 proteins was determined in serum-starved PC12 cells stimulated with $10 \mu \mathrm{M}$ nicotine as described previously (Shaw et al., 2002). At the end of stimulation, cells were washed twice with ice-cold PBSV (phosphate-buffered saline with $1 \mathrm{mmol} / \mathrm{N} \mathrm{Na}_{3} \mathrm{VO}_{4}$ ). Each dish was then treated for $60 \mathrm{~min}$ with ice-cold lysis buffer $(20 \mathrm{mmol} / \mathrm{l}$ Tris- $\mathrm{HCl}, \mathrm{pH} 7.4,2.5 \mathrm{mmol} / \mathrm{l}$ EDTA, $1 \%$ Triton X-100, $10 \%$ glycerol, $10 \mathrm{mmol} / 1 \mathrm{Na}_{4} \mathrm{P}_{2} \mathrm{O}_{7}, 50 \mathrm{mmol} / \mathrm{l}$ $\mathrm{NaF}, 1 \mathrm{mmol} / 1 \mathrm{Na}_{3} \mathrm{VO}_{4}$, and $1 \mathrm{mmol} / \mathrm{l} \mathrm{PMSF}$ ), and the supernatant fraction was obtained as cell lysate by centrifugation at 58,000 $\times g$ for $25 \mathrm{~min}$ at $4^{\circ} \mathrm{C}$. Samples were resolved by $10 \%$ SDS-PAGE, transferred to a nitrocellulose membrane, and blocked by $60 \mathrm{~min}$ incubation at $22^{\circ} \mathrm{C}$ in TTBS (TBS with $0.05 \%$ Tween 20 , pH 7.4) plus $5 \%$ skimmed milk powder. The nitrocellulose membrane was incubated overnight at $4^{\circ} \mathrm{C}$ with affinitypurified anti-phospho-specific JAK2 antibodies. The nitrocellulose membranes were washed 10 min twice with TTBS and incubated with goat anti-rabbit IgG horseradish peroxidase conjugate. After extensive washing, the bound antibody was visualized on a Kodak Biomax film (Eastman Kodak, Rochester, NY) using a Pierce Supersignal substrate chemiluminescence detection kit.

Immunoprecipitation studies of SHP-1. The cell lysate prepared as described above was incubated with $10 \mu \mathrm{g} / \mathrm{ml}$ anti-SHP-1 monoclonal antibodies at $4^{\circ} \mathrm{C}$ for $2 \mathrm{hr}$ and precipitated by addition of $50 \mu \mathrm{l}$ of protein $\mathrm{A} / \mathrm{G}$-agarose at $4^{\circ} \mathrm{C}$ overnight. The immunoprecipitates was recovered by centrifugation and washed three times with ice-cold wash buffer (TBS, $0.1 \%$ Triton X-100, $1 \mathrm{mmol} / \mathrm{l} \mathrm{PMSF}$, and $1 \mathrm{mmol} / 1 \mathrm{Na}_{3} \mathrm{VO}_{4}$ ). Immunoprecipitated proteins were dissolved in $100 \mu \mathrm{l}$ of Laemmli sample buffer, and $80 \mu \mathrm{l}$ of each sample was resolved by SDS-PAGE. Samples were transferred to a nitrocellulose membrane and blocked by 60 min incubation at room temperature $\left(22^{\circ} \mathrm{C}\right)$ in TTBS plus $5 \%$ skimmed milk pow- der. The nitrocellulose membrane was then incubated overnight at $4^{\circ} \mathrm{C}$ with $10 \mu \mathrm{g} / \mathrm{ml}$ affinity-purified anti-phosphotyrosine antibodies, and the bound antibodies were visualized using a Pierce Supersignal chemiluminescence detection kit.

SHP-1 tyrosine phosphatase activity assay. SHP-1 activity was determined as described previously (Marrero et al., 1998). Briefly, SHP-1 proteins were immunoprecipitated with anti-SHP-1 antibodies from PC12 cell lysates, and the immunocomplexes were washed three times with ice-cold wash buffer and then three times with phosphatase buffer (50 mm HEPES, $60 \mathrm{~mm} \mathrm{NaCl}, 60 \mathrm{~mm} \mathrm{KCl}, 0.1 \mathrm{~mm}$ PMSF, $10 \mu \mathrm{g} / \mathrm{ml}$ aprotinin, and $10 \mu \mathrm{g} / \mathrm{ml}$ leupeptin, $\mathrm{pH}$ 7.4). Phosphatase activity was measured by monitoring the rate of formation of $p$-nitrophenol by dephosphorylation of $p$-nitrophenyl phosphate. Immunocomplex pellets were resuspended in $100 \mu \mathrm{l}$ of phosphatase buffer containing $1 \mathrm{mg} / \mathrm{ml}$ BSA, 5 mm EDTA, and $10 \mathrm{~mm}$ dithiothreitol. The reaction was initiated by the addition of $p$-nitrophenylphosphate ( $10 \mathrm{~mm}$ final concentration). After the described period of incubation at room temperature, the reaction was stopped by the addition of $1 \mathrm{M} \mathrm{NaOH}$, and absorbance of the sample was determined at $410 \mathrm{~nm}$ in a spectrophotometer.

Antisense against SHP-1. An antisense oligonucleotide that targets the translational start site of the murine SHP-1 coding sequence (5'ACCTCACCATCCTTGGGGT-3') has been found to significantly reduce SHP-1 expression in human erythroleukemic SKT6 cells (Sharlow et al., 1997). Therefore, we tested the effect of this SHP-1 antisense phophorothiorate oligonucleotide on SHP-1 expression in PC12 cells. Briefly, for oligonucleotide transfections, PC12 cells were washed and resuspended in Optimem I medium at $1 \times 10^{6}$ cells $/ \mathrm{ml}$. Oligonucleotides in Optimem I medium and 1\% FBS (20 or $40 \mu \mathrm{mol} / \mathrm{l}$ ) were incubated with DMRIE-C ( $15 \mu \mathrm{g}$; Invitrogen) for $30 \mathrm{~min}$ at $23^{\circ} \mathrm{C}$. Liposomeoligonucleotide complexes were then incubated for $5 \mathrm{hr}$ at $37^{\circ} \mathrm{C}$ with $7.5 \times 10^{5}$ cells (total volume, $1.5 \mathrm{ml}$ ), and an equal volume of Optimem I medium containing $8 \% \mathrm{FBS}$ was added. For assays of SHP-1 expression, PC12 cells were collected, washed at $0^{\circ} \mathrm{C}$ in Optimem I medium, and lysed at $4^{\circ} \mathrm{C}$ in $20 \mathrm{mmol} / \mathrm{l} \mathrm{Tris}-\mathrm{HCl}, \mathrm{pH} 7.4,2.5 \mathrm{mmol} / \mathrm{l} \mathrm{EDTA}, 1 \%$ Triton $\mathrm{X}-100,10 \%$ glycerol, $10 \mathrm{mmol} / \mathrm{l} \mathrm{Na}{ }_{4} \mathrm{P}_{2} \mathrm{O}_{7}, 50 \mathrm{mmol} / \mathrm{l} \mathrm{NaF}, 1 \mathrm{mmol} / \mathrm{l}$ $\mathrm{Na}_{3} \mathrm{VO}_{4}, 1 \mathrm{mmol} / \mathrm{l} \mathrm{PMSF}$, and $2.2 \mu \mathrm{g} / \mathrm{ml}$ aprotinin $\left(3.0 \times 10^{6} \mathrm{cells} / 0.25\right.$ $\mathrm{ml}$ per sample). The cleared supernatant was then incubated with 10 $\mu \mathrm{g} / \mathrm{ml}$ anti-SHP- 1 monoclonal antibodies at $4^{\circ} \mathrm{C}$ for $2 \mathrm{hr}$ and precipitated by addition of $50 \mu \mathrm{l}$ of protein $\mathrm{A} / \mathrm{G}$-agarose at $4^{\circ} \mathrm{C}$ overnight. The immunoprecipitates was recovered by centrifugation and washed three times with ice-cold wash buffer (TBS, $0.1 \%$ Triton X-100, $1 \mathrm{mmol} / \mathrm{l}$ PMSF, and $1 \mathrm{mmol} / \mathrm{Na}_{3} \mathrm{VO}_{4}$ ). Immunoprecipitated proteins are dissolved in $100 \mu \mathrm{l}$ of Laemmli sample buffer, and $80 \mu \mathrm{l}$ of each sample was resolved by SDS-PAGE. Samples were transferred to a nitrocellulose membrane and blocked by $60 \mathrm{~min}$ incubation at room temperature $\left(22^{\circ} \mathrm{C}\right)$ in TTBS plus $5 \%$ skimmed milk powder. The nitrocellulose membrane was then incubated overnight at $4^{\circ} \mathrm{C}$ with $1 \mu \mathrm{g} / \mathrm{ml}$ anti-SHP-1 antibodies, and the bound antibodies were visualized using a Pierce Supersignal chemiluminescence detection kit.

Assessment of PC12 cell apoptosis. Apoptosis was determined by assessing the cleavage of the DNA-repairing enzyme PARP using a Western blot assay. PARP $(116 \mathrm{kDa})$ is an endogenous substrate for caspase-3, which is cleaved to a typical $85 \mathrm{kDa}$ fragment during various forms of apoptosis. PC12 cells were treated with $0.1 \mu \mathrm{M} \mathrm{A} \beta$ for $8 \mathrm{hr}$ in the presence or absence of $10 \mu \mathrm{M}$ nicotine and/or $100 \mathrm{nM}$ Ang II and/or SHP-1 antisense and/or $10 \mu \mathrm{M}$ of the JAK2-specific inhibitor AG-490 (Meydan et al., 1996; Dicou et al., 2001). The cells were collected, washed with PBS, and lysed in $1 \mathrm{ml}$ of SDS-PAGE sample buffer boiled for $10 \mathrm{~min}$. Total cell lysates (30 $\mu \mathrm{g}$ of protein) were separated by SDS-PAGE and transferred to nitrocellulose membranes. The membranes were blocked for $1 \mathrm{hr}$ at $25^{\circ} \mathrm{C}$ with $5 \%$ nonfat dry milk in TBST $(25 \mathrm{~mm}$ Tris- $\mathrm{HCl}, \mathrm{pH} 7.5,0.5 \mathrm{M}$ $\mathrm{NaCl}$, and $0.05 \%$ Tween 20 ). Membranes were incubated with primary PARP antibody specific for the $85 \mathrm{kDa}$ fragments for $2-3 \mathrm{hr}$ at $25^{\circ} \mathrm{C}$, rinsed with TBST, and incubated with secondary antibody for $1 \mathrm{hr}$ at $25^{\circ} \mathrm{C}$. Immunodetection was performed with appropriate antibody using an enhanced chemiluminescence system (Amersham Biosciences).

Caspase 3 enzyme activity was determined with a fluorogenic substrate for caspase-3 in crude PC12 cell extracts. The caspase 3 fluorogenic peptide Ac-DEVD-AMC (Promega, Madison, WI) contains the specific 


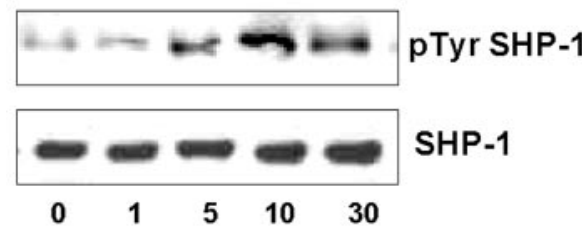

Time (Minutes)

Figure 1. Angiotensin II-induced tyrosine phosphorylation of SHP-1. PC12 cells were incubated for $24 \mathrm{hr}$ in serum-free medium before exposure to Ang II ( $100 \mathrm{~nm})$ for the times indicated. Cells were lysed, and SHP-1 was immunoprecipitated from lysates with $10 \mu \mathrm{g} / \mathrm{ml}$ anti-SHP-1 monoclonal antibodies at $4^{\circ} \mathrm{C}$ for $2 \mathrm{hr}$ and precipitated by addition of $50 \mu \mathrm{l}$ of protein A/Gagarose at $4^{\circ} \mathrm{C}$ overnight. Immunoprecipitated proteins were resolved by SDS-PAGE and transferred to a nitrocellulose. Immunoprecipitates were then immunoblotted with antiphosphotyrosine antibody. Shown are representative immunoblots of three immunoblots. pTyr, Tyrosine-phosphorylated.

caspase 3 cleavage sequence (DEVD) coupled at the $\mathrm{C}$ terminal to the fluorochrome 7-amino-4-methyl coumarin. The substrate emits a blue fluorescence when excited at a wavelength of $360 \mathrm{~nm}$. When cleaved from the peptide by the caspase 3 enzyme activity in the cell lysate, free 7-amino-4-methyl coumarin is released and can be detected by its yellow-green emission at $460 \mathrm{~nm}$. Appropriate controls included a reversible aldehyde inhibitor of caspase 3 to assess the specific contribution of the caspase 3 enzyme activity (data not shown). Fluorescence units were normalized relative to total protein concentration of the cell extract. We performed the assays in triplicate and repeated the experiments three times. In addition, we measured the decrease in PC12 cell number using a Coulter counter (model ZM; Coulter, Hialeah, FL).

Data analysis. All statistical comparisons were made using Student's $t$ test for paired data and ANOVA. Significance was $p<0.05$.

\section{Results}

Ang II-induced activation of SHP-1 and its effects on nicotine-induced tyrosine phosphorylation of JAK2

At present, no functional role has been demonstrated for SHP-1 activation by the $\mathrm{AT}_{2}$ receptor, and it is interesting to note that SHP-1 can function as a negative regulator of JAK2 signaling (Marrero et al., 1998). Therefore, the potential biological significance of $\mathrm{AT}_{2}$ receptor-induced programmed cell death led us to investigate whether SHP-1 activation could be involved in this process. First, we discovered that Ang II induced both the tyrosine phosphorylation (Fig. 1) and the activation (Fig. 2) of SHP-1. Because there are no specific pharmacological inhibitors of SHP-1 available, we used antisense probes to suppress the expression of SHP-1 in PC12 cells. An antisense oligonucleotide that targets the translational start site of the murine SHP-1 coding sequence ( $5^{\prime}$-ACCTCACCATCCTTGGGGT-3') has been found to significantly reduce SHP-1 expression in human erythroleukemic SKT6 cells (Sharlow et al., 1997). PC12 cells were treated with the sense or antisense phophorothiorate oligonucleotides for various times, SHP-1 was immunoprecipitated, and the immunoprecipitates were immunoblotted with anti-SHP-1 antibody. As shown in Figure 3, the antisense (but not the sense) oligonucleotide was effective in completely inhibiting SHP-1 expression within 6-8 hr. We then determined the effects of treatment with antisense oligonucleotides on the nicotine-induced activation of JAK2 via SHP-1, because we showed previously that preincubation of PC12 cells for $8 \mathrm{hr}$ with Ang II blocked the nicotineinduced tyrosine phosphorylation of JAK2 via the $\mathrm{AT}_{2}$ receptor (Shaw et al., 2002). PC12 cells were stimulated with nicotine in the presence or absence of Ang II lysed, and JAK2 was then immunoprecipitated from the lysates with anti-JAK2 antibody. Im-

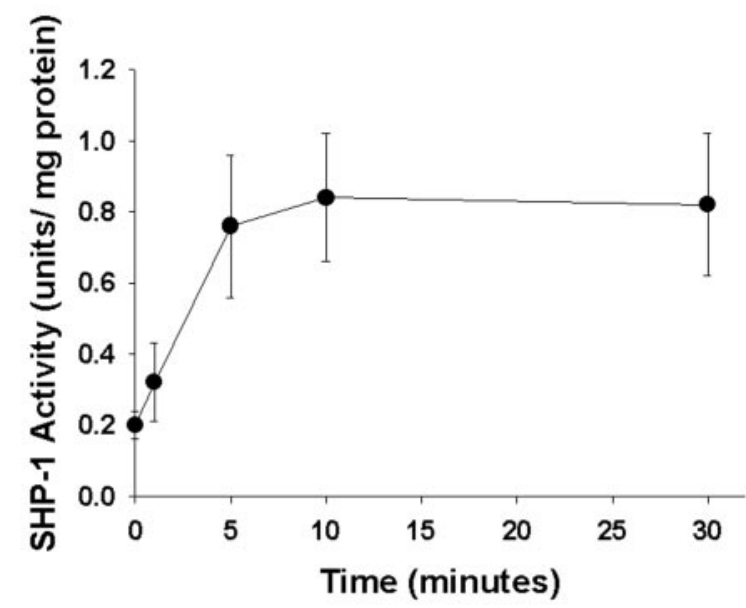

Figure 2. Angiotensin I--induced activation of SHP-1. PC12 cells were incubated with Ang II $(100 \mathrm{~nm})$ for the times indicated. The cells were lysed, and SHP-1 was immunoprecipitated from lysates with an anti-SHP-1 antibody. Immunoprecipitates were assayed for SHP-1 activity by measuring the rate of formation of $p$-nitrophenol from $p$-nitrophenylphosphate. Data represent the mean \pm SE from six experiments.

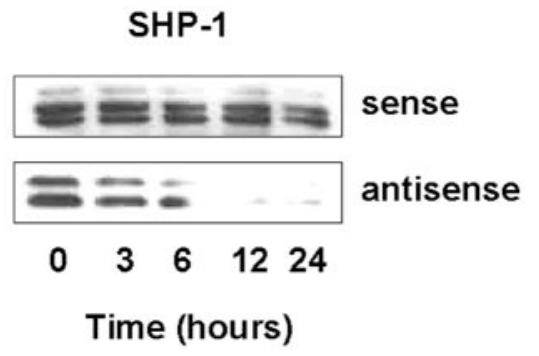

Figure 3. Effect of SHP-1 sense and antisense oligonucleotides on SHP-1 expression in PC12 cells. PC12 cells were treated with SHP-1 sense and antisense oligonucleotides for the times indicated and lysed. SHP-1 was immunoprecipitated from the lysates with anti-SHP-1 antibody. Precipitated SHP-1 proteins were then immunoblotted with specific anti-SHP-1 antibody. Shown are representative immunoblots of three immunoblots.

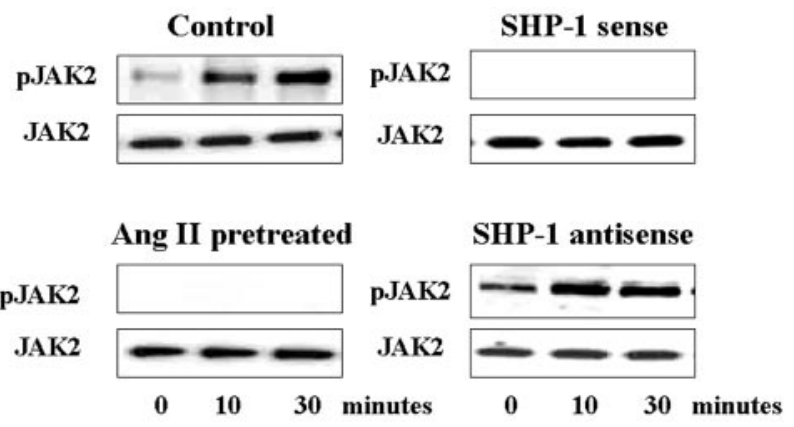

Figure 4. Effects of angiotensin II pretreatment with either SHP-1 antisense or sense on nicotine-induced activation of JAK2. Cells preincubated with Ang II for $8 \mathrm{hr}$ in the presence or absence of SHP-1 antisense or sense oligonucleotides were stimulated with nicotine for the time indicated. Cells were immunoblotted with phospho-specific and non-phospho-specific anti-JAK2. Shown are representative immunoblots of three immunoblots. p, Phosphorylated.

munoprecipitated proteins were separated by gel electrophoresis, transferred to nitrocellulose, and then immunoblotted with antiphosphotyrosine antibody. Control cells were exposed to SHP-1 sense oligonucleotide. As shown in Figure 4, when cells were exposed to the SHP-1 antisense, JAK2 tyrosine phosphorylation was augmented and the Ang II blockage of the nicotine-induced tyrosine phoaphorylation of JAK2 was obliterated. These results 


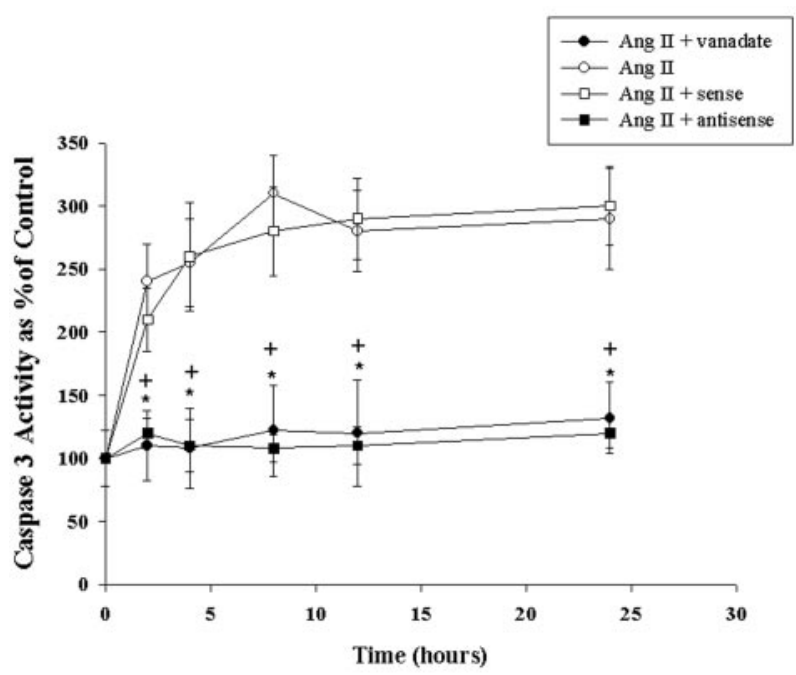

Figure 5. Effects of SHP-1 antisense on the angiotensin II-induced activation of caspase-3. PC12 cells were incubated for the duration shown with Ang II in the presence of either SHP-1 antisense or SHP-1 sense or vanadate. Caspase-3 activities are shown as the mean \pm SE of six independent cultures.

suggest that SHP-1 is the PTPase that is activated by Ang II and dephosphorylates JAK2 after nicotine-induced JAK2 phosphorylation in PC12 cells.

\section{Assessment of PC12 cell apoptosis}

Caspase 3 is expressed in PC12 cells and is known to be involved in apoptosis (Shaw et al., 2002). We examined caspase 3 activity after Ang II-induced apoptosis. We used the fluorescent peptide substrate Ac-DEVD-AMC to measure caspase 3-like activity in cell lysates. As shown in Figure 5, the caspase 3-like activity that resulted in the cleavage of the peptide substrate Ac-DEVD-AMC is evident after $2 \mathrm{hr}$ of Ang II treatment and increased over time until it reached a peak after $8 \mathrm{hr}$ of treatment. However, the Ang II-induced activation of caspase 3 was blocked significantly in the presence of SHP-1 antisense $(+p<0.01)$ or vanadate $\left({ }^{*} p<0.01\right)$ (Fig. 5). Coincubation with the SHP-1 sense had no effect on the Ang II-induced activation of caspase 3.

Apoptosis was also determined by assessing the cleavage of the DNA-repairing enzyme PARP using a Western blot assay. PC12 cells are treated with $0.1 \mu \mathrm{M} \mathrm{A} \beta$ for $8 \mathrm{hr}$ in the presence or absence of nicotine. As shown in Figure 6, PARP $(116 \mathrm{kDa})$ was cleaved to its $85 \mathrm{kDa}$ fragment after $\mathrm{A} \beta$ (1-42) treatment. The $\mathrm{A} \beta$ (1-42)induced cleavage of PARP was blocked by nicotine and prevented by AG-490 and Ang II (Fig. 6). However, in the presence of SHP-1 antisense, the Ang II blockage of the nicotine anti-apoptotic effects against $A \beta$ (1-42)-induced cleavage of PARP was aborted (Fig. 6). These results support our main hypothesis, which states that JAK2 plays a central role in the nicotinic $\alpha 7$ receptorinduced activation of JAK2 in PC12 cells, which ultimately contributes to nicotine-induced neuroprotection, and that Ang II blocks these effects through the $\mathrm{AT}_{2}$-mediated receptor activation of the PTPase SHP-1.

\section{Discussion}

In this study, we found that the nicotine neuroprotective effects, which can be neutralized through activation of the Ang II $\mathrm{AT}_{2}$ receptor, are reversed by nullifying the PTPase SHP-1 as evidenced by the usage of an antisense against SHP-1. The SHP-1 antisense not only augmented the nicotine-induced tyrosine

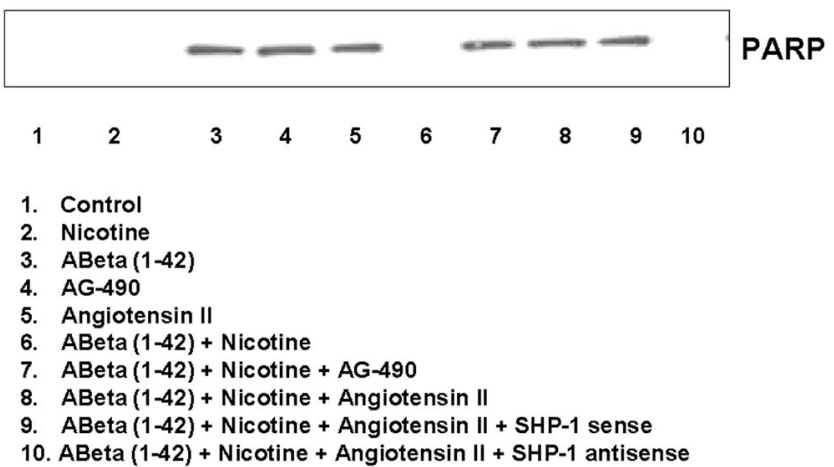

Figure 6. Effects of SHP-1 antisense on nicotine-induced protection against A $\beta$ - and Ang II-induced apoptosis. PARP expression was measured from lysates of cells treated for $8 \mathrm{hr}$ by $A \beta$ (1-42) peptide and/or Ang II in the presence or absence of nicotine and/or SHP-1 antisense. Shown is a representative immunoblot of three immunoblots.

phosphorylation of JAK2 but also blocked the Ang II neutralization of the nicotine-induced neuroprotection against $\mathrm{A} \beta$ (1-42)induced cleavage of PARP.

Several reports have documented the apoptotic effects of Ang II through $\mathrm{AT}_{2}$ receptors. $\mathrm{AT}_{2}$ receptors are expressed in $\mathrm{PC1}$ and have been shown to inhibit the JAK-STAT (signal transducer and activator of transcription) signaling cascade (Kunioku et al., 2001). In contrast to nicotine-induced neuroprotection against $\mathrm{A} \beta$ (1-42), pretreatment of cells with Ang II blocks the nicotineinduced activation of JAK2 via the $\mathrm{AT}_{2}$ receptor and completely prevents nicotine-mediated neuroprotective effects, further suggesting a pivotal role for JAK2 phosphorylation (Shaw et al., 2002). Our findings, in this study, are again consistent with the opposite roles on cell viability that exists between the $\alpha 7 \mathrm{nAChR}$ and the $\mathrm{AT}_{2}$ receptor, with activation of the $\mathrm{AT}_{2}$ receptor overriding the potential survival benefit through the $\alpha 7 \mathrm{nAChR}$. These results and the convergence of these pathways on phosphorylated JAK2 suggest that recruitment of nicotinic $\alpha 7$ receptor-mediated neuroprotection against $\mathrm{A} \beta$ (1-42) may be optimized under conditions in which the $\mathrm{AT}_{2}$-mediated inhibition is minimized by blocking the $\mathrm{AT}_{2}$-induced activation of SHP-1. The findings in this study identify novel molecular mechanisms that are fully consistent with the role attributed to $\alpha 7$ nAChR-induced activation of JAK2 and subsequent neuroprotective effect, as well as the $\mathrm{AT}_{2}$-induced activation of SHP-1 and its alleged role in apoptotic events.

SHP-1 is a soluble tyrosine phosphatase that participates in the negative regulation of the tyrosine kinase JAK2 (Marrero et al., 1998). It has been reported recently that stimulation of $\mathrm{AT}_{2}$ receptors rapidly activates $\mathrm{SHP}-1$ in N1E-115 and $\mathrm{AT}_{2}$ transfected Chinese hamster ovary cells (Horiuchi et al., 1998; Lehtonen et al., 1999). In the present study, we also document that $\mathrm{AT}_{2}$ receptors activate SHP-1 in PC12. Moreover, the onset of SHP-1 activation clearly precedes the onset of JAK2 inhibition and apoptosis, thus suggesting that SHP-1 is an upstream, proximal effector in $\mathrm{AT}_{2}$ signaling. In addition, to establish a functional link between $\mathrm{AT}_{2}$-mediated activation of SHP-1 and inactivation of JAK2, we used an antisense oligonucleotide of SHP-1 and demonstrated that preventing SHP-1 activation abrogates $\mathrm{AT}_{2}$-induced JAK2 inhibition. Furthermore, the termination of $\mathrm{AT}_{2}$ receptor-mediated apoptosis in PC12 cells via transfection of the SHP-1 antisense oligonucleotides additionally supports the concept that the proapoptotic effect of $\mathrm{AT}_{2}$ is associated with the inhibition of JAK2 via a signaling pathway involving the activa- 
tion of SHP-1. Altogether, these observations suggest that SHP-1 is a transducer of the proapoptotic signals mediated by the $\mathrm{AT}_{2}$ receptor, probably through negative regulation of the $\alpha 7 \mathrm{nAChR}$ signaling pathway.

Nicotinic neurotransmission is compromised in the brains of $\mathrm{AD}$ patients, and accumulating evidence suggests that nAChRselective ligands can offer neuroprotective effects in a number of in vitro models, including neuronal death resulting from $\beta$-amyloid toxicity, NMDA-mediated cytotoxicity, or growth factor deprivation, and in in vivo models, including chemically induced neurotoxicity (1-methyl-4-phenyl-1,2,3,6-tetrahydropyridine models and systemic kainic acid-induced excitotoxic effects). Nicotinic ligands reduce $\beta$-amyloid aggregation and toxicity and inhibit amyloid deposition in transgenic mice with APPsw (amyloid precursor protein containing the Swedish mutation) (Nordberg et al., 2002). A recent report has demonstrated that the $\alpha 7 \mathrm{nAChR}$ is also an essential regulator of inflammation and is required for inhibition of cytokines release (Wang et al., 2003). The physiological mechanism coined "the cholinergic anti-inflammatory pathway," which has been proposed to have major implications in immunology and therapeutics, remains unknown. The induction and resolution of inflammatory processes are the complex outcome of interplay between pro-inflammatory and antiinflammatory cytokines. Pleiotropic cytokines, such as interleukin-6 (IL-6) and IL-10, have been shown to activate the JAK-STAT pathway and act in opposition to effects mediated by the pro-inflammatory cytokines IL-1 and tumor necrosis factor- $\alpha$ (Ahmed and Ivashkiv, 2000). It is conceivable from these findings that multifaceted therapeutic potential targeting cognitive deficits, neuroprotection, and inflammation in neurodegenerative diseases can be recruited through a single pharmacology targeting the $\alpha 7 \mathrm{nAChR}$. It remains to be established whether similar pathways are operative for these various end points in vivo and whether the negative influence of $\mathrm{AT}_{2}$ stimulation is clinically relevant. However, the putative beneficial effects of angiotensin converting enzyme inhibitors in Alzheimer's disease and the observation of selective upregulation of $\mathrm{AT}_{2}$ receptor density (Ge and Barnes, 1996) and biosynthetic enzymes (Savaskan et al., 2001) concurrent with downregulation of nAChR in the temporal cortex of some AD patients (Court et al., 2001) is consistent with the opposite effects on cell viability observed in our studies through activation of $\mathrm{AT}_{2}$ and $\alpha 7$-nAChR.

\section{References}

Ahmed ST, Ivashkiv LB (2000) Inhibition of IL-6 and IL-10 signaling and Stat activation by inflammatory and stress pathways. J Immunol 165:5227-5237.

Bencherif M, Lovette ME, Fowler KW, Arrington S, Reeves L, Caldwell WS, Lippiello PM (1996) RJR-2403: a nicotinic agonist with CNS selectivity. I. In vitro characterization. J Pharmacol Exp Ther 279:1413-1421.

Court J, Martin-Ruiz C, Piggott M, Spurden D, Griffiths M, Perry E (2001) Nicotinic receptor abnormalities in Alzheimer's disease. Biol Psychiatry 49:175-184.

de Fiebre CM, Meyer EM, Henry JC, Muraskin SI, Kem WR, Papke RL (1995) Characterization of a series of anabaseine-derived compounds reveals that the 3-(4)-dimethylaminocinnamylidine derivative is a selective agonist at neuronal nicotinic alpha 7/125I-alpha-bungarotoxin receptor subtypes. Mol Pharmacol 47:164-171.

Dicou E, Attoub S, Gressens P (2001) Neuroprotective effects of leptin in vivo and in vitro. NeuroReport 12:3947-3951.

Donnelly-Roberts DL, Xue IC, Arneric SP, Sullivan JP (1996) In vitro neuroprotective properties of the novel cholinergic channel activator (ChCA), ABT-418. Brain Res 719:36-44.

Ge J, Barnes NM (1996) Alterations in angiotensin AT1 and AT2 receptor subtype levels in brain regions from patients with neurodegenerative disorders. Eur J Pharmacol 297:299-306.

Horiuchi M, Akishita M, Dzau VJ (1998) Molecular and cellular mechanism of angiotensin II-mediated apoptosis. Endocr Res 24:307-314.

Kem WR (2000) The brain alpha7 nicotinic receptor may be an important therapeutic target for the treatment of Alzheimer's disease: studies with DMXBA (GTS-21). Behav Brain Res 113:169-181.

Kihara T, Shimohama S, Sawada H, Honda K, Nakamizo T, Shibasaki H, Kume T, Akaike A (2001) alpha 7 nicotinic receptor transduces signals to phosphatidylinositol 3-kinase to block A beta-amyloid-induced neurotoxicity. J Biol Chem 276:13541-13546.

Kunioku H, Inoue K, Tomida M (2001) Interleukin-6 protects rat PC12 cells from serum deprivation or chemotherapeutic agents through the phosphatidylinositol 3-kinase and STAT3 pathways. Neurosci Lett 309:13-16.

Lehtonen JY, Daviet L, Nahmias C, Horiuchi M, Dzau VJ (1999) Analysis of functional domains of angiotensin II type 2 receptor involved in apoptosis. Mol Endocrinol 13:1051-1060.

Marrero MB, Venema VJ, Ju H, Eaton DC, Venema RC (1998) Regulation of angiotensin II-induced JAK2 tyrosine phosphorylation: roles of SHP-1 and SHP-2. Am J Physiol 275:C1216-C1223.

Meydan N, Grunberger T, Dadi H, Shahar M, Arpaia E, Lapidot Z, Leeder JS, Freedman M, Cohen A, Gazit A, Levitzki A, Roifman CM (1996) Inhibition of acute lymphoblastic leukaemia by a Jak-2 inhibitor. Nature 379:645-648.

Newhouse PA, Potter A, Kelton M, Corwin J (2001) Nicotinic treatment of Alzheimer's disease. Biol Psychiatry 49:268-278.

Nordberg A, Hellstrom-Lindahl E, Lee M, Johnson M, Mousavi M, Hall R, Perry E, Bednar I, Court J (2002) Chronic nicotine treatment reduces beta-amyloidosis in the brain of a mouse model of Alzheimer's disease (APPsw). J Neurochem 81:655-658.

Ryan RE, Ross SA, Drago J, Loiacono RE (2001) Dose-related neuroprotective effects of chronic nicotine in 6-hydroxydopamine treated rats, and loss of neuroprotection in alpha4 nicotinic receptor subunit knockout mice. Br J Pharmacol 132:1650-1656.

Savaskan E, Hock C, Olivieri G, Bruttel S, Rosenberg C, Hulette C, MullerSpahn F (2001) Cortical alterations of angiotensin converting enzyme, angiotensin II and AT1 receptor in Alzheimer's dementia. Neurobiol Aging 22:541-546.

Seo J, Kim S, Kim H, Park CH, Jeong S, Lee J, Choi SH, Chang K, Rah J, Koo J, Kim E, Suh Y (2001) Effects of nicotine on APP secretion and A. Biol Psychiatry 49:240-247.

Sharlow ER, Pacifici R, Crouse J, Batac J, Todokoro K, Wojchowski DM (1997) Hematopoietic cell phosphatase negatively regulates erythropoietin-induced hemoglobinization in erythroleukemic SKT6 cells. Blood 90:2175-2187.

Shaw S, Bencherif M, Marrero MB (2002) Janus kinase 2, an early target of alpha 7 nicotinic acetylcholine receptor-mediated neuroprotection against Abeta-(1-42) amyloid. J Biol Chem 277:44920-44924.

Wang H, Yu M, Ochani M, Amella CA, Tanovic M, Susarla S, Li JH, Wang H, Yang H, Ulloa L, Al-Abed Y, Czura CJ, Tracey KJ (2003) Nicotinic acetylchone receptor $\alpha 7$ subunits is an essential regulator of inflammation. Nature 421:384-388. 